\title{
Вітамій Серьогін
}

\section{РЕЦЕНЗІЯ НА МОНОГРАФЮЮ Г. ХРИСТОВОЇ «ПОЗИТИВНІ ЗОБОВ'ЯЗАННЯ ДЕРЖАВИ У СФЕРІ ПРАВ ЛЮДИНИ: СУЧАСНІ ВИКЛИКИ»'}

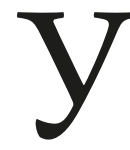

продовж історії розвитку АюАства вплив прав АюАини на всі явища та фактори суспільної Аійсності був суттєвим; вони визначали сутність, зміст права, його цінність та процес функціонування. Виникло навіть поняття «етика прав

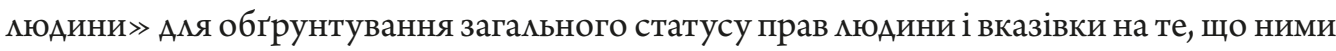
має керуватися у своїх вчинках кожна мюдина. В умовах гуманізації національного й міжнародного права «люАський вимір» стає головним критерієм оцінки внутрішньої та зовнішньої політики держав, поклаАаючи на держави делаці більше зобов'язань як негативного, так і позитивного характеру. За Ааних умов монографія Г. Христової «Позитивні зобов' язання Аержави у сфері прав АюАини: сучасні виклики» є своєчасним і грунтовним віАгуком на новітні виклики у сфері прав АюАини, що постали переА світовою спільнотою на початку XXI століття.

У рецензованій монографії на піАставі новітніх піАходів до розуміння прав АюАини визначено типи й особливості зобов'язань держави у сфері прав мюАини, проаналізовано зміст, обсяг та межі позитивних зобов'язань з урахуванням свободи розсуду держави та принципу пропорційності, а також охарактеризовано національні правові рамки їх виконання. Авторкою преАставцено систематизований викцаА позитивних зобов'язань Аержави стосовно основоположних прав і свобод у світлі сталої практики Європейського суАу з прав мюАини й узагацьнено віАповіАні європейські стандарти таких зобов'язань. 3 огляАу на сучасні виклики розглянуто піАхоАи Ао позитивних зобов'язань держави в особливих умовах й запропоновано типологію таких зобов'язань у ситуаціях збройного конфмікту, тимчасової окупації та внутрішнього переміщення.

Значущість монографії Г. Христової полягає, перш за все, у тому, що в ній розкрито оАну з сутнісних ознак сучасного етапу розвитку концепції прав АюАини - важливість активної й добросовісної поведінки держави щодо захисту і забезпечення прав АюАини.

\footnotetext{
* Віталій Олександрович Серьогін, Аоктор юридичних наук, професор, професор кафеАри конституційного і муніципального права, Харківський націонацьний університет імені В. Н. Каразіна.

Vitalii Serohin, Doctor of Legal Sciences, Professor at the Department of Constitutional and Municipal Law, V. N. Karazin Kharkiv National University.

e-mail: 4.v. a. seryogin@karazin.ua

${ }^{1}$ Ганна Христова, Позитивні зобов'язання держави у сфері прав ююдини: сучасні виклики (Харків: Право, 2018). Ganna Khrystova, Positive Human Rights Obligations of the State: Current Challenges (Kharkiv: Pravo, 2018) (in Ukrainian).
} 
Загалом рецензована монографія являє собою цілісне і професійно оформлене АосліАження широкого кола взаємопов'язаних наукових проблем щодо концептуалізації позитивних зобов'язань Аержави у сфері прав мюдини в умовах мирного часу та суспільної небезпеки, з урахуванням принципів і піАходів Європейської конвенції прав ^юАини як конституційного інструменту європейського публічного поряАку.

Передусім сліА віАзначити вАалу спробу авторки окреслити обсяг та межі розуміння

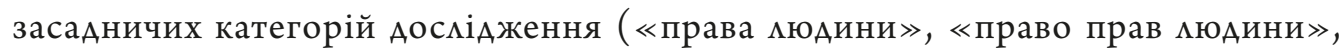
«зобов’ язання держави у сфері прав АюАини» тощо) і запропонувати їх типологію, що має методологічне значення в контексті представценої праці. Ао надважливих висновків роботи у цьому аспекті належать твердження про уніфікацію піАходів до розуміння прав мюАини та віАповіАних зобов'язань Аержави ( з урахуванням окремих неминучих елементів фрагментарності), аАже в протилежному випаАку це загрожувало б стабільності та передбачуваності різних систем захисту прав Аюдини, призводимо до їх Аисбалансу.

Так, авторкою послідовно доведено, що, виходячи з їх основних принципів та вмас-

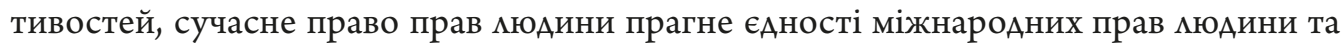
основоположних прав, захищених конституціями й конкретизованих на рівні національного законодавства. ААже всі права Аюдини та основоположні свободи, незалежно віА засобів їх інституціоналізації та інструментів захисту на міжнародному чи національному рівнях, мають мати єАиний (або принаймні близький) зміст та є неподільними, взаємопов' язаними та взаємозалежними.

У рецензованій монографії переконливо продемонстровано, що сформовані в різних системах правозахисту (оонівській, європейській, міжамериканській) зобов'язання Аержави за «трирівневою» типологією поважати, захищати й забезпечувати права ююАини не суперечать сучасним уявленням про Аихотомію негативних і позитивних зобов'язань, зобов' язання Аії й результату, а також про зобов'язання належної сумлінності (належної уваги). Авторкою справеАливо стверАжується, що узгоАжене розуміння різних типів зобов'язань держави у сфері прав мюдини має принципово важливе значення Аля вАосконалення механізму їх реалізації, аАже Аержави мають гарантувати права Аюдини у межах національної правової системи віАповіАно Ао своїх міжнародних зобов' язань.

Заслуговує на беззастережну піАтримку теза авторки про те, що обов'язок Аержав вживати заходів (законодавчих, судових, адміністративних, освітніх та ін.) Аля забезпечення особам можливостей задовольняти основні потреби, гарантовані правом прав мюдини, що не можуть бути задоволені ї особистими зусимяями, стосується не тільки економічних, соціальних та культурних прав, але й громаАянських та політичних. Фактично це означає, що системний характер мають не тільки основні права АюАини, але й кореспондуючі їм обов'язки держави, що має позначатися на їі політиці.

На особливу увагу заслуговує ключовий висновок про те, що позитивні зобов'язання також можуть бути «наслідком негативного права». Авторкою обгрунтовується, що 
виключно негативний піАхіА Ао гарантування прав АюАини не може забезпечити їх реального й ефективного захисту, оскільки поведінка приватних осіб може загрожувати правам мюАини так само, як і діяльність (бездіяльність) органів, що наділені публічною владою. ВіАповіАно держава має вживати всіх належних та можливих заходів Аля попереАження зазіхань і захисту віА порушень усіх категорій прав АюАини також з боку приватних осіб. Як наголошується, цінність такого піАходу не у тому, щоб принципово замінити собою подіц прав на негативні та позитивні, а у тому, щоб жодний теоретик не міг би напомягати, що «конкретна реальність реалізації певного права» настільки проста, що може бути зведена мише Ао негативних чи позитивних зобов'язань.

Такий піАхіА зміщує акценти у розумінні позитивних зобов'язань віА суто «забезпечувальної» Аіяльності Аержави стосовно соціально-економічних прав, у бік «захисного обов'язку Аержави» віА можливих порушень усіх груп прав мюАини як з боку Аержави в особі органів публічної влаАи, так і з боку приватних осіб. Це Аозволяє переосмислити роль Аержави, аАже позитивні зобов'язання стосуються Аержави як гаранта, «наАійного партнера» у захисті віА зазіхань на права мюАини та їх віАновленні, на віАміну віА розуміння Аержави як «потенційного порушника» прав АюАини, що має негативні зобов'язання, тобто зобов'язання утримуватися віА втручання, або «всевлаАного покровителя в умовах Аержавного протекціонізму.

Г. Христова цілком слушно звертає увагу на маловідому у вітчизняній юриспруденції концепцію зобов'язань «належної сумлінності (або «належної уваги» чи «належної обачності») (англ. «due diligence obligations »), яка вимагає віА Аержави застосування всіх можливих захоАів Аля попереАження порушень тих чи інших прав АюАини, захисту віА таких порушень, покарання за них та належної компенсації постражАалим. Важливо, щоб ця концепція отримувала дедалі більше відображення в національному законодавстві та помітико-правовій практиці України.

Аосить продуктивним виявився проведений авторкою аналіз АосвіАу врахування Європейської конвенції та Аоктрини прав мюАини у конституційній юриспруденції України з урахуванням принципу Аружнього ставлення до міжнародного права у тлумаченні Конституційного Суду України, що має узгоджуватися з практикою ЄСП . Цілком обгрунтованою є теза авторки про те, що запроваджена в Україні модель «нормативної» конституційної скарги не стане націонацьним «фільтром» Аля всіх справ переА спрямуванням індивідуацьних заяв до ЄСП $\Lambda$, оскільки на практиці порушення прав Аюдини частіше спричинені не «технічно правильним застосуванням» неконституційного закону, який може бути оскаржено через цей виА скарги, а $є$ результатом неконституційного індивіАуального акта, який можливо, але не обов'язково, прийнятий на піАставі закону, що віАповідає Конституції. Заслуговує на піАтримку пропозиція авторки щодо забезпечення можиивості визнання неконституційності закону через наявність у ньому законодавчої прогалини всупереч вимогам Конституції, що призвело Ао порушення прав мюАини через невиконання позитивних зобов'язань (принаймні у випаАках, коли мінімальний обсяг віАповіАних зобов' язань чітко визнаний у сталій 
практиці ЄСП , інших міжнародних юрисАикційних органів з прав Аюдини або національній конституційній юриспруденціі).

Розкриваючи основні елементи доктрини позитивних зобов'язань Аержави у сфері прав мюдини, Г. Христова слушно пропонує розрізняти так звані «горизонтальні» й «соціальні» позитивні зобов’язання. Перші стосуються захисту прав мюАини між приватними особами, а Аругі відтворюють функцію, на виконання якої спрямовані такі зобов' язання, а саме забезпечення «ефективного користування правами мюдини у соціальній Аійсності» заАля реалізації повної автономії та свободи особи. Авторка піАкреслює, що вказані групи позитивних засобів можуть бути юридичними (напр., законоАавче закріплення прав АюАини, встановлення юридичних вимог Аля зАійснення певного роду Аіяльності або нормативна регламентація повеАінки певних категорій осіб), чи практичними (зокрема, обов'язок Аержави вжити всіх практичних захоАів Аля запобігання вбивству чи нанесенню тілесних ушкоджень особам, які перебувають піА вартою, або запобігти самогубству засуджених). Крім того, авторкою виокремлено матеріальні («cубстантивні ) ) позитивні зобов'язання, які передбачають забезпечення основних засобів, необхіАних Аля повного володіння й користування гарантованими правами мюдини, та процедурні (напр., провеАення ефективного, оперативного й невіАклаАного розслідування випадків порушення прав мюдини незалежними компетентними особами).

Не лише академічна, а й істотна практична, інструментальна цінність АосліАження визначається представленим у монографії широким узагальненням та систематизацією позитивних зобов'язань Аержави щодо окремих прав і свобод з урахуванням практики ЄСПИ (права на життя, заборони катування, рабства і примусової праці, права на свободу та особисту неАоторканність, на справеАливий суА, на повагу Ао приватного і сімейного життя, свободи Аумки, совісті і релігії, вираження погляАів, зібрань та об'єАнання, права безперешкодно володіти своїм майном, права на вільні вибори, на освіту, заборони дискримінаціі). Викладені у монографії положення, які розкривають Аетальний зміст віАповіАних обов'язків держави, покликані сприяти вАосконаленню національного судового захисту прав АюАини, вкАючно з конституційним правосуААям, через застосування практики ЄСП А як Ажерела права, а також спрямуванню щоденної Аіяльності адміністративних і правоохоронних органів України у бік виконання позитивних зобов'язань держави.

Нарешті, Аосить сміливою, але разом із тим успішною видається спроба Г. Христової продемонструвати застосовність конструкції позитивних зобов'язань держави Ао ситуації збройного конфмікту, тимчасової окупації та вимушеного внутрішнього переміщення. ВіАповіАна проблематика вимагала віА авторки скрупульозного загальнотеоретичного осмислення, передовсім у контексті функціонування національних правових систем в особливих умовах. Це, зокрема, стосується питань віАступу Аержави віА зобов'язань у сфері прав АюАини піА час суспільної небезпеки, екстратериторіальної Аії права прав мюдини, віАповіАних зобов'язань окупаційної держави та Аержави, постражАалої віА збройного конфмікту, та ін. У піАсумку авторці вАалося довести, що піАходи (стандарти), 
які визначають наявність позитивних зобов' язань, їх обсяг і характер, а також використовуються Аля оцінки їх виконання з боку держави, $є$ іАентичними в умовах мирного часу та в ситуації суспільної небезпеки, що загрожує життю нації.

Загалом сліА віАзначити, що монографія Г. Христової «Позитивні зобов’язання Аержави у сфері прав Аюдини: сучасні виклики» віАзначається високим науково-метоАологічним рівнем виконання, вмілим використанням сучасного науково-методологічного арсеналу, виваженістю й обгрунтованістю висновків, високою правовою культурою теоретичних побудов. Переважна більшість висновків авторки являють собою суттєве прирощення наукового знання у сфері теоретичної юриспруденції та можуть бути успішно використані на практиці. Специфіка предмета дослідження вимагала віА авторки глибоких знань не тільки з загамьної теорії держави і права, але й з міжнародного права, а також конституційного, цивільного і низки інших галузей національної системи права, і вона такі знання яскраво виявила, успішно вирішивши всі поставцені переА нею наукові завдання. Рецензована монографія, без сумніву, буде корисною як фахівцям у галузі загальної теорії права, прав мюдини, конституціоналізму, так і широкому колу громаАськості, усім, хто цікавиться проблематикою прав мюАини в умовах мирного часу й суспільної небезпеки.

(C) В. Серьогін, 2019

Віталій Серьогін. Рецензія на монографію Г. Христової «Позитивні зобов'язання Аержави у сфері прав мюАини: сучасні викАики»

Анотація. Аналіз змісту монографії Ганни Христової «Позитивні зобов’язання держави у сфері прав викцики у сфері прав ююАини, що постали перед світовою спільнотою на початку ХХІ століття.

Витахий Серегин. Рецензия на монографию А. Христовой «Позитивные обязательства государства в сфере прав человека: современные вызовы»

Аннотация. Анализ содержания монографии Анны Христовой «Позитивные обязательства государства в сфере прав человека: современные вызовы» как своевременного и глубокого отклика на новейшие вызовы в сфере прав человека, стоящие переА мировым сообществом в начаме XXI века.

Vitalii Serohin. A Review of Monograph by G. Khrystova «Positive Human Rights Obligations of the State: Current Challenges»

Abstract. Revew of the book by Ganna Khrystova «Positive Human Rights Obligations of the State: Current Challenges» (in Ukrainian) as a timely and thorough response to the resent human rights challenges facing the world at the beginning of the 21 st century.

ОАержано / Received 15.11.2019 